\title{
IBNU KHALDUN: \\ KAJIAN TOKOH SEJARAH DAN ILMU-ILMU SOSIAL
}

\author{
Samsinas \\ STAIN Datokarama Palu, Jl. Diponegoro 23 Palu \\ e-mail: baiqsinas@yahoo.com
}

\begin{abstract}
Abstrak
This paper deals with Ibn Khaldun and his theory of circle (cyclical theory). This theory is based on historical realities in nomadic societies and also urban societies which have their own social solidarity, organizational structure and civilization. From this fact, he is known as the first figure who construct scientifically the methodology of the history of human thought, so that history can be developed both as science and philosophy. Subsequently, Ibn Khaldun's ideas become the seeds for the development of social sciences, including sociology and economics.
\end{abstract}

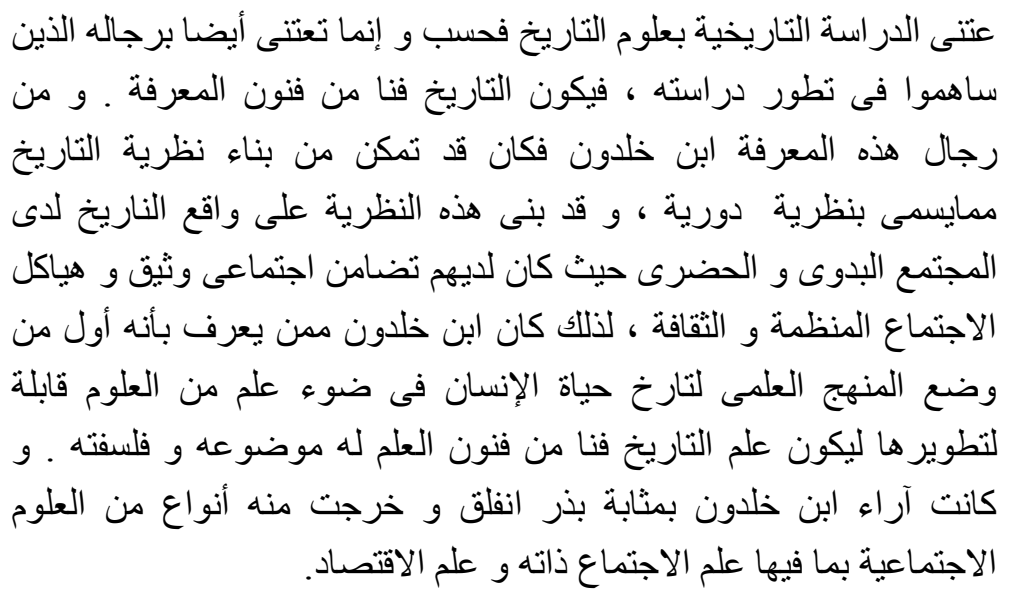

Kata Kunci: Ibnu Khaldun, sejarah sosial, filsafat sejarah, ilmu-ilmu sosial 


\section{PENDAHULUAN}

Sejarah adalah pertanggungjawaban masa silam. Dan manusialah yang menentukan arti masa silam itu. Artinya masa silam itu bukanlah masa silam sebagai tabu la rasa. Melainkan masa silam yang lembaran-lembarannya telah ditulis oleh manusia dengan tindakan-tindakannya. Tindakan-tindakan itulah yang dinamakan sejarah-sebagai-peristiwa.

Sarwono Pusposaputro, dalam Sartono Kartodirdjo (1982:v) mengatakan bahwa manusia berhak dan wajib memberikan arti sehingga sejarah-sebagai-peristiwa menjadi sejarah-sebagai-kisah, sejarah-sebagai-tulisan, yang mempunyai pokok kaidah sejarah sebagai ilmu.

Alquran sendiri pada dasarnya adalah sejarah dan memuat kisahkisah sejarah tentang berbagai peristiwa para Nabi masa silam. Melalui Alquran dan tulisan sejarah lainnya, umat Islam mempelajari dan memahami Islam serta perjuangan dan keagungan nabi Muhammad dalam melaksanakan dakwahnya di masa silam.

Ada tiga persoalan pokok yang harus tercatat dalam tulisan sejarah, yaitu (1) peristiwa masa lampau (materi sejarah); (2) deskripsi tentang masa lampau; dan (3) tokoh sejarah atau sejarahwan. Tokoh sejarah adalah pelaku sejarah sedangkan sejarahwan adalah ilmuwan yang menguasai dan meneliti pertumbuhan dan perkembangan sejarah manusia.

Sekitar tahun 484-425 sebelum Masehi, seorang tokoh dikenal sebagai "bapak" sejarahwan, Herodotus, untuk pertama kalinya meletakkan dasar penulisan sejarah. Namun, penulisan sejarah pada masa itu hanya memusatkan perhatian pada pemberitaan fakta-fakta yang diambil dari sumber sejarah yang sezaman dengannya, akibatnya tidak bisa dikembangkan oleh ilmuwan pada masa belakangan (Ramadhan, 2009).

Pada abad XIV M, sejarah peradaban umat manusia termasuk yang berkaitan dengan kebangkitan dan kejatuhan bangsa-bangsa khususnya di dunia Islam, seorang tokoh besar bernama Ibnu Khaldun tampil sebagai politikus dan pelaku sejarah sekaligus memberikan makna sejarah sebagai sebuah tulisan-kisah-sejarah yang berarti bagi kehidupan dan keilmuwan masyarakat di dunia Muslim pada abad kemudian. Dunia keilmuwan melirik karya-karya Ibnu Khaldun dalam 
suatu discourse tertentu terutama dalam kajian ilmu sejarah dan sosiologi. Pemikiran-pemikiran Ibnu Khaldun dianggap penting dalam upaya membangun peradaban masyarakat dunia, khususnya di dunia Muslim.

Adalah Franz Rosenthal, orientalis pertama yang memiliki perhatian terhadap sarjana-sarjana Islam yang hidup di abad ke-14, inilah awal penerjemahan atas muqaddimah Ibn Khaldun, sehingga Ibnu Khaldun bangkit kembali sebagai sarjana muslim yang dikenal dunia sekarang ini. Perhatian terhadap Ibnu Khaldun ini diteruskan oleh Muhsin Mahdin, sarjana muslim asal Irak yang lama mengajar di Univresitas Chicago dan Universitas Harvard, melalui kajiannya atas filsafat sejarah Ibnu Khaldun. Mahdin meninggal bulan Juli 2007 dalam usia 81 tahun. Minatnya terhadap pemikiran Ibnu Khaldun antara lain diilhami oleh gurunya di Universitas Chicago, Leo Strauss, seorang filsuf dan sarjana besar Yahudi asal Jerman yang juga dikenal karena penelitiannya tentang Al-Farabi (Abdallah, 2008).

Pada kenyataannya, pemikiran-pemikiran Ibnu Khaldun menjadi diskursus bukan hanya dilakukan di negara-negara Muslim, tetapi juga di Negara Barat, termasuk Spanyol (Andalusia), tempat Ibnu Khaldun pernah aktif di kancah politik dan birokrasi selama bertahun-tahun.

Ibnu Khaldun menunjukkan karakter intelektualnya kepada dunia melalui karyanya yang fenomenal al-'Ibar atau Muqaddimah. Bahkan setelah masyarakat dunia mengkaji karya-karyanya, pemikirannya justru menjadi cikal bakal "Filsafat Sejarah" dan atau Ilmu Sejarah. Selain itu, di bidang sosiologi, para pelajar berubah haluan dari yang sebelumnya mengakui Auguste Comte sebagai "Bapak Sosiologi", kemudian menganggap bahwa yang pantas disebut "Bapak Sosiologi" adalah Ibnu Khaldun. Melalui Muqaddimah-nya, Ibnu Khaldun telah memberikan "janin" bagi sosiologi yang dilahirkan pada abad sebelum Auguste Comte dengan teori positivismnya.

Kita dapat mencoba menggali pemikiran Ibnu Khaldun yang cukup monumental dan komperehensif dalam karyanya sebanyak enam bab, sebagaimana yang terkandung dalam Muqadimah-nya, yaitu (1) tentang peradaban umat manusia secara umum, corak dan pembagiannya menurut ilmu bumi; (2) tentang peradaban padang pasir (masyarakat pengembala), kabilah dan bangsa pengembara; (3) tentang negara-negara, khalifah, kekuasaan raja, dan pembicaraan 
tentang tingkatan pemerintahan; (4) tentang peradaban orang-orang menetap, kota-kota dan provinsi-provinsi; (5) tentang keahlian, mata pencaharian, usaha hidup dan segala aspeknya; dan (6) tentang ilmu pengetahuan, cara memperoleh dan mempelajarinya (Ibnu Khaldun, 2000:68).

Artikel ini akan menguraikan beberapa pemikiran Ibnu Khaldun dan pandangan ilmuwan terhadap pemikiran-pemikirannya. Hal ini merupakan discourse bagi pengembangan keilmuwan di bidang Ilmu Sejarah, Filsafat Sejarah dan Sosiologi. Dalam tulisan ini, kami juga memaparkan pemikiran Ibnu Khaldun di bidang ekonomi dalam pandangan beberapa ahli ekonomi.

\section{RIWAYAT HIDUPNYA}

Ibnu Khaldun lahir di Tunis Afrika Barat Laut pada tanggal 25 Mei tahun $1332 \mathrm{M}$. atau tahun $732 \mathrm{H}$., dari keturunan keluarga bangsawan Banu Khaldun. Banu Khaldun bermigrasi ke Tunisia pasca jatuhnya Saville ke Reconquesta pada pertengahan abad ke-13. Di bawah kekuasaan seorang Tunisia, Keluarga Ibnu Khaldun memegang beberapa jabatan politik. Namun kemudian bapak dan kakeknya menarik diri dari dunia politik dan menjalani kehidupan spiritual (a mystic order) (Al-Tanji,1951:1).

Semasa hidupnya, beliau membantu berbagai sultan di Tunisia, Maroko, Spanyol dan Aljazair sebagai duta besar, bendaharawan dan anggota dewan penasehat sultan (Goodman, 2004:8).

Tidak banyak catatan sejarah yang menceritakan riwayat masa kecil atau masa mudanya. Namun, Ibnu Khaldun dikenal sebagai anak yang sudah menguasai Alquran dan bahasa Arab pada usia yang relatif muda. Dia juga menguasai ilmu-ilmu klasik, seperti filsafat, metafisika dan tasawuf. Disamping itu, dia tertarik dengan geografi, sejarah dan ilmu ekonomi. Pada usia 20 Tahun, beliau telah diangkat menjadi sekretaris Sultan Abu Inan di Fez, Maroko. Setelah itu beliau menjadi Perdana Menteri Sultan Buogie (Sekarang Aljazair), kemudian pada tahun 1366 M., Ibnu Khaldun pindah ke Konstantinopel dan diangkat menjadi pembantu Raja Abdul Abbas. Kemudian Ia pindah ke Biskra (daerah selatan Konstantinopel). Pada tahun 1375 M. ia mulai berkencimpung di dunia keilmuwan (Ramadhan, 2009). 
Kritikannya bahwa penguasa negara bukanlah pemimpin yang mendapatkan kekuasaan dari Tuhan menyebabkan Ibnu Khaldun dipenjara selama 2 tahun di Maroko. Selama kurang lebih dua dekade aktif di bidang politik, serta menyaksikan penyusutan peradaban dan perpecahan di dunia Islam. Hal ini mendorong beliau untuk menganalisa sebab-sebabnya. Beliau pun lalu meneliti kekacauan politik yang terjadi di Afrika Barat Laut (Lauer, 2003:41).

Ibnu Khaldun mengundurkan diri dari kehidupan politik dan kembali ke Afrika Utara. Di situ dia melakukan studi dan menulis secara intensif selama 5 tahun dan menghasilkan karya-karya yang menyebabkan beliau terkenal dan diangkat menjadi guru besar studi Islam di Universitas Al-Azhar Kairo. Dalam mengajarkan tentang masyarakat dan ilmu-ilmu sosial, Ibnu Khaldun menekankan pentingnya menghubungkan pemikiran sosiologi dan observasi sejarah.

Menjelang kematiannya tahun 1400 M., Ibnu Khaldun telah menghasilkan sekumpulan karya yang mengandung berbagai pemikiran yang mirip dengan sosiologi jaman sekarang. Dia melakukan studi Ilmiah tentang masyarakat, riset empiris, dan meneliti sebab-sebab fenomena sosial. Ia memusatkan perhatian pada berbagai lembaga sosial (misalnya lembaga politik dan ekonomi) dan hubungan antara lembaga sosial itu. Ia juga melakukan studi perbandingan antara masyarakat primitif dan masyarakat modern atau tentang masyarakat nomaden dengan masyarakat menetap.

Ibnu Khaldun tak berpengaruh secara dramatis terhadap sosiologi klasik, tetapi setelah sarjana pada umumnya dan sarjana muslim khususnya meneliti ulang karyanya, ia mulai diakui sebagai sejarahwan yang mempunyai signifikansi historis (Goodman, 2004:8).

Ibnu Khaldun bukan hanya seorang intelektual, tetapi juga praktisi politik. Pergulatannya dengan politik mengantarkannya terlibat di berbagai kancah politik di wilayah barat Afrika Utara seperti Tunisia, Aljazair, dan Maroko, hingga ke Andalusia dan kemudian Timur Tengah. Namun, semangat intelektualitasnya tidak pernah padam. Di saat jeda, dia masih sempat menjalankan kerja intelektualnya dengan meneliti dan berkarya, termasuk menulis buku sosiologi politik kenegaraan. Muqadimah-nya banyak diperbincangkan para ahli selama berabad-abad. Intelektualitasnya 
tidak hanya berputar di sekitar idea dan wacana, melainkan membumi ke dunia nyata, bahkan ke realitas politik, sosial dan ekonomi.

Tidak banyak sosok yang dapat meraih posisi yang menonjol dalam intelektualitas dan politik sekaligus seperti beliau, bahkan di dunia modern sekarang. Ibnu Khaldun yang sempat mengambil jarak dari kekuasaan pun tak mampu menahan diri untuk tidak terjun kembali ke politik di usia tuanya. Ibnu Khaldun sempat melahirkan karya besar. Jika tidak, tak akan ada nama Ibnu Khaldun yang dikenang dunia seperti sekarang.

\section{POKOK PIKIRANNYA TENTANG SEJARAH}

Ketika dunia Barat belum memiliki pemikir di bidang sejarah dan sosiologi, dan dunia Islam masih terkungkung dengan pemahaman profane bahwa kenyataan hidup dan kehidupan manusia adalah kehendak Tuhan semata, Ibnu Khaldun muncul dengan kecerdasan ilahiah melalui pemikiran-pemikiran yang sangat original dan baru tentang sejarah manusia. Ibnu Khaldun seakan membuka tabir sejarah manusia di balik kehendak Tuhan dengan mengungkapkan teori sejarah secara realistis berdasarkan fenomena sosial yang ada dan berjalan di atas hukum kausalitas.

Menurut dia, sejarah tidak hanya diungkap secara faktual tetapi yang lebih penting adalah hukum kausalitas sejarah itu sendiri harus diungkapkan. Sebuah peristiwa sejarah harus dilihat dari berbagai aspek, baik itu aspek ekonomi, politik, sosial, agama, dan lain sebagainya. Sehubungan dengan itu, dalam tulisan ini akan diuraikan beberapa teori Ibnu Khaldun berdasarkan Muqaddimah-nya.

\section{Teori Siklus}

Pokok pikirannya yang terpenting adalah teori sejarah masyarakat manusia sebagai proses tak berujung (unlimited process), berputar dan mengulang terus menerus itulah yang oleh ilmuwan menyebutnya dengan teori Lingkaran atau teori Siklus Ibnu Khaldun. Teori ini dibangun berdasarkan penelitiannya pada rangkaian proses sejarah masyarakat sosial-politik di benua Afrika yaitu sekitar Tunisia, Maroko, dan Aljazair. Dan secara praktis Ibnu Khaldun ikut terlibat dalam proses sejarah tersebut.

Berdasarkan kajian yang tertuang dalam Muqaddimah-nya, teori siklus ini dapat diklasifikasi sebagai berikut: 


\section{Sejarah Sosial}

Dalam Kehidupan masyarakat di Afrika, atau yang berlatar belakang masyarakat Barbar, Ibnu Khaldun membagi dua kelompok masyarakat, yaitu masyarakat nomaden (Badui) dan masyarakat menetap. Berdasarkan pada objek kajiannya mengenai masyarakat nomaden atau masyarakat primitif dan masyarakat menetap atau masyarakat kota (Madinah). Ibnu Khaldun memandang bahwa mobilitas masyarakat nomaden merupakan proses sejarah dan masyarakat kota yang menetap adalah masyarakat yang terorganisir dan berperadaban. Dalam perjalanannya menuju perubahan-perubahan yang signifikan, masyarakat akan berhadapan dengan berbagai problem yang lahir dari perbedaan-perbedaan yang ada dalam kelompok masyarakat yang akan berproses kepada tujuan yang diingingkan bersama. Dalam mencapai tujuan itu diperlukan kerjasama dan solidaritas dalam suatu masyarakat atau kelompok secara terorganisir, baik dalam bentuk kelompok sosial, kesukuan maupun negara.

Pada intinya, Ibnu Khaldun berbicara tentang asal mula negara manusia sebagai makhluk politik, manusia yang membutuhkan orang lain dalam mempertahankan hidupnya sehingga kehidupannya dengan masyarakat dan organisasi sosial merupakan sebuah keharusan (Ibnu Khaldun, 2000:41).

Lebih lanjut, manusia hanya mungkin bertahan untuk hidup dengan bantuan makanan sedang untuk memenuhi kebutuhan makanan yang sedikit dengan waktu satu hari saja memerlukan banyak rangkaian pekerjaan. Sebagai contoh, butir-butir gandum yang akan menjadi potongan roti memerlukan proses yang panjang, butirbutir tersebut harus ditumbuk kemudian diolah menjadi adonan, lalu dibakar. Sebelum disiapkan untuk dibuat dan dimakan dibutuhkan alat-alat yang untuk mengadakannya, dibutuhkan kerja sama dengan tukang pandai kayu/besi, dan seterusnya (Ibnu Khaldun, 2000:41).

Manusia memerlukan perlindungan hidup dengan pertahanan yang terorganisir dan suatu organisasi masyarakat memerlukan pemimpin (khalifah) (Ibnu Khaldun, 2000:43). Setelah oganisasi masyarakat terbentuk dan terlaksana maka inilah yang disebut masyarakat peradaban. Menurutnya, tujuan masyarakat nomaden pada hakekatnya adalah menjadi masyarakat menetap atau masyarakat kota 
(citizen). Dan "umran" yang dalam kesarjanaan modern diterjemahkan sebagai "peradaban", dapat diartikan sebagai "urbanisme" atau gejala mengkota. Sebab apa yang disebut sebagai umran oleh Ibnu Khaldun selalu dikaitkan dengan fenomena kota (al-had $\square$ ar) sebagai lawan dari gejala masyarakat Badui yang cenderung nomaden.

Dalam bagian ini Ibnu Khaldun mengemukakan suatu observasi yang menarik yang paralel dengan teori sosiologi modern mengenai pembagian kerja dan diferensiasi sosial.

Ia mengatakan bahwa masyarakat yang belum mencapai suatu kematangan dalam urbanisme dimana kota-kotanya belum berkembang (tatamaddan al-madinah) cenderung memusatkan diri pada usaha untuk mencukupi kebutuhan subsistem, yaitu mengusahakan bahan pangan pokok (al-aqwat). Setelah tahap ini terlampau, dan kota-kota mereka kian maju, serta sejumlah bidang pekerjaan (al-a'mal) mulai muncul, maka pelan-pelan mereka akan mulai memanfaatkan surplus kekayaan yang ada (al-zai'd) untuk halhal yang bersifat kemewahan hidup "luxuries" (al-kamâlat min alma'âsh).

\section{Solidaritas Sosial}

As $\square$ abiyyah inilah yang melambungkan namanya dimata para pemikir moderen. Peradaban badui, orang kota dan solidaritas sosial (as $\square$ abiyyah) menurut Ibnu Khaldun merupakan faktor pembentuk negara (dawlah). As $\square$ abiyyah yang mengandung makna group feeling, solidaritas kelompok, fanatisme kesukuan, nasionalisme atau sentimen sosial yaitu cinta dan kasih sayang seorang manusia kepada saudara atau tetangganya ketika salah satu darinya diperlakukan tidak adil atau disakiti. Hal ini memunculkan dua kategori sosial fundamental yaitu badawah (komunitas pedalaman, masyarakat primitif atau daerah gurun) dan had $\square$ arah (komunitas masyarakat kota, beradab) sebagai fenomena yang alamiah dan niscaya (Ibnu Khaldun, 2000:43).

Sifat-sifat kepemimpinan selalu dimiliki oleh orang-orang yang memiliki solidaritas sosial. Setiap suku biasanya terikat pada keturunannya yang bersifat khas maupun umum. Setiap kaum harus ada solidaritas sosial yang berada di atas solidaritas masing-masing individu, sebab apabila masing-masing individu meyakini keunggulan solidaritas sosial sang pemimpin maka akan siap untuk tunduk dan patuh mengikutinya (Ibnu Khaldun, 2000:132). 
Kelompok padang pasir yang liar lebih kuat dan mudah menaklukan masyarakat kota. Ini adalah hasil penelitiannya pada masyarakat Barbar (Ibnu Khaldun, 2000:138). Tujuan akhir solidaritas adalah kedaulatan. Dan solidaritas sosial dapat mempersatukan tujuan, mempertahankan diri dan mengalahkan musuh.

Kemudian ketika satu kelompok solidaritas sosial yang menguasai negara sudah tua maka akan digantikan atau direbut oleh solidaritas sosial lain yang lebih kuat atau merekruk pemimpin dari kelompok yang sudah tua bergandengan tangan dengan pemimpin kelompok solidaritas sosial lain yang lebih kuat. Itulah yang terjadi pada orang-orang Turki yang masuk ke dalam kedaulatan Bani Abbas (Ibnu Khaldun, 2000:132).

\section{Persaudaraan Berdasarkan Kesamaan Keyakinan (Mu'akhah)}

Menurut Ibnu Khaldun persamaan ketuhanan (mu'akhah), yaitu solidaritas yang dibangun berdasarkan persaudaraan atas kesamaan keyakinan membuat mereka berhasil mendirikan Dinasti, karena menurutnya bangsa Arab adalah bangsa yang tidak mau tunduk kepada satu sama lain, kasar, angkuh dan ambisius. Maka yang menjadi pemimpin pada bangsa Arab adalah pemimpin suku/kabilah bukan dinasti. Itulah kenapa Nabi diturunkan di wilayah Arab. Hegemonitas kelompok dapat disatukan oleh keyakinan agama (Ibnu Khaldun, 2000:132).

Khilafah adalah pemerintahan yang berlandaskan agama yang memerintahkan rakyatnya sesuai dengan petunjuk agama, baik dalam hal duniawi maupun ukhrawi. Oleh karena itu, pemerintahan yang berlandaskan agama disebut dengan "khilâfah", "imâmah", atau "sult $\square$ ânah", sedangkan pemimpinnya disebut "khalîfah" atau "imâm" atau "sult $\square \hat{a} n$ ". Khalifah adalah pengganti Nabi Muhammad, dengan tugas mempertahankan agama dan menjalankan kepemimpinan dunia, lembaga imâmah adalah wajib menurut hukum agama, yang dibuktikan dengan dibai'atnya Abu Bakar sebagai khalifah, tetapi ada juga yang berpendapat, imâmah wajib karena akal/atau perlunya manusia terhadap organisasi sosial. Namun, hukum wajibnya adalah Fard $\square$ Kifâyah (Ibnu Khaldun, 2000:191-193).

Ibnu Khaldun menetapkan lima syarat bagi khalifah/imam/ sultan: (1) memiliki pengetahuan, (2) memiliki sifat-sifat adil, (3) mempunyai kemampuan (memimpin), (4) sehat fisik dan panca indra, 
(5) Keturunan Quraisy berdasarkan teori As $\square$ abiyyah (Ibnu Khaldun, 2000:194).

Menurut Ibnu Kaldun keturunan Quraisy memiliki keutamaan, yaitu orang-orang Quraisy adalah pemimpin-pemipin terkemuka, original dan tampil dari Bani Mudhar, solidaritas kelompoknya kuat, memiliki wibawah yang tinggi, maka tidak heran jika pemimpin agamanya dipercayakan pada suku Quraisy. Nabi menginginkan persatuan solidaritas dan persaudaraan (Ibnu Khaldun, 2000:191-193) Meski demikian jika solidaritas suku Quraisy lemah, maka dimungkinkan suku lain yang lebih kuat solidaritasnya pada saat itu.

\section{Politik dan Ulama}

Menurut Ibnu Khaldun, ada tiga bentuk pemerintahan dalam suatu Negara, yaitui: pertama, pemerintahan yang natural (siyâsah $t \square \hat{a b i}$ 'iyyah), yaitu pemerintahan yang membawa masyarakat sesuai dengan tujuan nafsu. Artinya, seorang raja lebih mementingkan keinginan nafsunya ketimbang rakyatnya. Akibatnya, rakyatnya tidak mau mentaati pemerintahannya, maka terjadilah teror, penindasan dan anarki. Pada zaman sekarang disebut pemerintahan otokratik; kedua, pemerintahan berdasarkan nalar (siyâsah 'aqlîyah), yaitu, pemerintahan yang membawa rakyatnya sesuai rasio dalam mencapai kemaslahatan duniawi dan mencegah kemudharatan pemerintahan yang berdasarkan undang-undang, dibuat oleh para cendekiawan. Pada zaman sekarang serupa dengan pemerintahan republik dan kerajaan institusional. Karena hanya mampu mewujudkan keadilan sampai batas tertentu; ketiga; Pemerintah berdasarkan agama (siyâsah diniyyah), yaitu pemerintahan yang membawa semua rakyatnya sesuai dengan ketentuan agama baik yang bersifat keduniawian maupun ukhrawi. Model pemerintahan seperti ini menurut Ibnu Khaldun (2000:191) adalah pemerintahan yang berlandaskan agama Islam. Kepala negara disebut khalifah, imam atau sultan karena mereka harus berperan sebagai pengganti nabi dalam memelihara kelestarian agama dan kesejahteraan duniawi dan rakyatnya. Imam sebagai pemimpin negara ibarat imam dalam salat yang harus diikuti oleh rakyat sebagai makmum.

Dari pembagian di atas, tampak bahwa Ibnu Khaldun menempuh jalur baru dibandingkan dengan Al-Farabi dan Ibnu AlKabi dalam mengklasifikasikan pemerintahan. Ia tidak memandang 
sisi personalnya juga bukan pada jabatan imam melainkan pada makna fungsional keimamahan itu sendiri. Sehingga menurutnya substansi setiap pemerintahan adalah undang-undang yang menjelaskan karakter suatu sistem pemerintahan.

Mengenai timbul dan tenggalamnya suatu negara peradaban, Ibnu Khaldun (2000:173) memberikan klasifikasi sebagai berikut: pertama, tahap konsolidasi, di mana otoritas negara didukung oleh masyarakat yang berhasil yang menggulingkan dinasti sebelumnya; kedua, tahap tirani, yaitu upaya menyelesaikan masalah konflik internal dalam rangka proses kematangan pemerintahan dengan mengakomodasi berbagai kepentingan yang berbeda, tetapi jika ada yang melawan maka akan dilakukan pemusnahan bahkan dengan cara kekerasan seperti yang terjadi pada masa pemerintahan Al-Abbas dari Bani Abbas pascaperalihan wewenang politik dari Dinasti Bani Umayyah. Al-Abbas mengejar dan membunuh orang-orang Bani Umayyah bahkan pendukungnya sendiri yang dianggap berpotensi melakukan pembangkangan politik seperti pada Abu Muslim AlKhurasani dan pamannya sendiri; ketiga, tahap distribusi pembangunan, yaitu pemimpin dan rakyatnya tercurah pada usaha membangun negara dan kesejahteraan rakyatnya dalam berbagai aspek; keempat, tahap ketenangan. Pada tahap ini merupakan tahap yang diharapkan semua pihak, baik pemimpin maupun rakyatnya, yaitu kepuasan hati, tenteram dan damai. Hal ini sebagaimana digambarkan dalam sejarah pemerintahan Khalifah Harun Al-Rasyid dari Dinasti Bani Abbas atau dalam sejarah pemerintahan Umar bin Abd Aziz dari Dinasti Bani Umayyah; dan kelima, tahap hidup boros. Tahap inilah yang cenderung membuat para pemimpin dan rakyatnya lengah pada kewajiban dan tanggung jawabnya. Ini akan menjadi biang masalah dalam pemerintahan dan kehancuran sebuah rezim politik.

Adapun ulama, menurut Ibnu Khaldun, harus jauh dari persoalan-persoalan politik dan hal-hal yang rumit. Ibnu Khaldun berbicara tentang "ulama" adalah manusia yang paling jauh dari politik dan seluruh cabang-cabangnya. Ulama cenderung jauh atau menjauh politik karena watak mereka yang lebih cenderung tenggelam atau menenggelamkan diri dalam dunia ide dan refleksi intelektual (mu'tadun al-naz $\square \hat{a r}$ al-fikrî wa al-ghaus 'alâ al-ma'âni). Mereka cenderung melakukan abstraksi, dalam pengertian mencari pola-pola 
umum dari data-data empirik yang terserak. Minat mereka bukan pada fakta-fakta empiris yang bersifat sporadis dan carut marut, tetapi mencari pola-pola umum, atau apa yang disebut oleh Ibnu Khaldun sebagai "umur kulliyyah 'ammah" (Abdalla, 2008).

Ibnu Khaldun justru meninggalkan tradisi Al-Farabi yang melihat pilitik sebagai wilayah kerja "para filosof" seperti dalam kerangka pemikiran Plato. Wawasan Ibnu Khaldun jelas lebih empirik.

\section{Model Generasi Politik}

Ibnu Khaldun juga memiliki gambaran tentang model generasi politik. Dalam hal ini menurut dia, ada tiga model generasi, yaitu (1) generasi pembangun yang dengan segala kesederhanaan di atas solidaritas yang tulus di bawah otoritas kekuasaan yang didukukungnya; (2) generasi penikmat, yaitu mereka yang karena diuntungkan secara ekonomi dan politik dalam sistem kekuasaan menjadi tidak peka lagi terhadap kepentingan bangsa dan Negara; dan (3) generasi yang tidak lagi memiliki hubungan emosional dengan negara. Mereka dapat melakukan apa saja yang mereka sukai tanpa memperdulikan nasib negara jika suatu bangsa sudah sampai pada generasi ketiga maka keruntuhan negara sebagai sunatullah sudah diambang pintu (Abdalla, 2008:172).

Menurut Ibnu Khaldun, ketiga model generasi ini ada secara bergantian dalam beberapa kali proses pemerintahan atau berada dalam rentang waktu sekitar satu abad. Sebuah peradaban besar dimulai generasi dari masyarakat yang telah di tempa dengan kehidupan keras, kemiskinan dan penuh perjuangan. Keinginan hidup yang makmur dan terbatas dari kesusahan hidup ditambah dengan As $\square$ abiyyah di antara mereka membuat mereka berusaha keras untuk mewujudkan cita-cita mereka dengan perjuangan yang keras. Impian yang tercapai kemudian memunculkan sebuah peradaban baru. Kemudian diikuti dengan kemunduran peradaban (Abdalla, 2008:172). Tahapan-tahapan ini kemudian terulang lagi, dan begitulah seterusnya. Berdasar ini pula, menurut Ibnu Khaldun, tidak ada status $q u o$, karena keniscayaan proses sejarah manusia yang selalu berubah dan berputar. 


\section{Filsafat Sejarah}

Ibnu Khaldun memperkenalkan bahwa terjadinya keberlangsungan masyarakat nomaden dan masyarkat kota harus mengenal faktor-faktor penyebabnnya demikian pula terhadap kekacauan politik di dunia Islam masa itu. Dalam Muqaddimah-nya Ibnu Khaldun menguraikan metodologi penelitian sejarah dan penjelasan sejarah umat manusia. Ibnu Khaldun tidak hanya sebagai pelaku sejarah tetapi juga ilmuwan sejarah yang dapat melahirkan teori-teori baru berdasarkan hasil penelitian empiris dan sangat metodologis.

Menurut Ibnu Khaldun (2000:173), hakekat sejarah adalah catatan tentang masyarakat ummat manusia. Sejarah itu sendiri identik dengan peradaban dunia, tentang revolusi, dan pemberontakan oleh segolongan yang lain dengan akibat timbulnya kerajaan-kerajaan dan negara-negara dengan berbagai macam tingkatannya; tentang kegiatan dan kedudukan orang, baik untuk mencapai penghidupannya maupun dalam ilmu pengetahuan dan pertukangan; dan pada umumnya tentang segala perubahan yang terjadi dalam peradaban karena watak peradaban itu sendiri adalah sunnatullah.

Ia menyadari bahwa penulisan sejarah sudah wataknya cenderung mengalami kebohongan. Hal ini disebabkan oleh beberapa faktor, antara lain:

- semangat terlibatnya sejarahwan atau penulis sejarah kepada pendapat-pendapat atau mazhab-mazhab.

- akibat terlalu percaya pada orang yang menukilkan sehingga memerlukan personality criticism.

- ketidaksanggupan memahami maksud yang sebenarnya dari hasil observasinya.

- asumsi yang tak beralasan terhadap kebenaran sesuatu hal termasuk akibat terlalu percaya pada para penukil.

- ketidaktahuan tentang bagaimana kondisi-kondisi sesuai dengan realitas, disebabkan kondisi-kondisi itu dimasuki oleh ambisiambisi dan distorsi-distorsi artifisial serta tidak mempunyai gambaran yang benar tentang kondisi-kondisi tersebut.

- adanya fakta bahwa kebanyakan manusia cenderung ingin dipuji atau kepentingan politik sehingga informasi yang disampaikannya cenderung tidak jujur. 
- kebohongan sejarah yang tidak dapat dihindarkan adalah ketidaktahuan tentang berbagai watak berbagai kondisi yang muncul dalam peradaban (Ibnu Khaldun, 2000:58-59).

Sehubungan dengan peradaban umat manusia, Ibnu Khaldun (2000:71) mengatakan organisasi kemasyarakatan merupakan suatu keharusan karena manusia adalah makhluk yang bersifat politis menurut tabiatnya. Menurut dia, tanpa organisasi itu eksistensi manusia tidak akan sempurna. Umat manusia memerlukan seorang yang akan melaksanakan kewibawaan dan memelihara mereka karena permusuhan dan kezaliman adalah merupakan watak hewani yang dimiliki oleh manusia. Senjata yang dibuat manusia untuk pertahanan dari serangan binatang tidaklah mencukupi bagi pertahanan terhadap serangan sesama manusia. Dan ini tidaklah mungkin datang dari luar. Oleh karena itu, dengan sendirinya orang yang akan melaksanakan kewibawaan itu haruslah seorang di antara mereka sendiri. Ia harus menguasai mereka dan mempunyai kekuatan dan wibawa melebihi mereka sehingga tak seorang pun di antara mereka sanggup menyerang yang lainnya dan inilah yang dinamakan kekuasaan (mulk) atau kedaulatan (Ibnu Khaldun, 2000:73-74).

Berkaitan dengan teori lingkaran sejarah, Ibnu Khaldun mengatakan bahwa sejarah mengalami perulangan konstan. Ibnu Khaldun melihat keteraturan lingkaran kehidupan peradaban menyerupai lingkaran kehidupan organisme: tumbuh-dewasa-uzur. Rentang waktu lingkaran kehidupan rezim politik kurang lebih sama, yaitu sekitar 100 tahun atau selama tiga generasi. Ada lingkaran perubahan ikatan sosial atau solidaritas kelompok dalam kehidupan sehari-hari. Perubahannya melalui tiga tahap, yaitu (1) ada solidaritas sangat kuat yang ditimbulkan oleh kekerasan kondisi kehidupan nomaden di gurun pasir; (2) munculnya kultur kehidupan menetap di lokasi tertentu dan meningkatnya kemakmuran memperburuk ikatan kelompok dan memperlemah solidaritas; dan (3) ini menyebabkan hancurnya solidaritas sosial, membubarkan kelompok, lalu diikuti oleh kristalisasi kelompok berdasarkan solidaritas sosial baru (Sztompka, 2007:168).

\section{Beberapa Pandangan terhadap Pemikiran Ibnu Khaldun}

Menurut Ulil Absar Abdalla, Muqaddimah, karya Ibnu Khaldun memuat banyak sekali observasi atas masyarakat manusia. Yang menurutnya layak dibaca dan dikaji hingga sekarang. Buku ini adalah 
salah satu hasil "Jenius" dalam sejarah Islam yang sangat mengagumkan (Abdallah, 2008).

Menurut Johnson (1986:15), Ibnu Khaldun memberikan suatu deskripsi historis mengenai masyarakat-masyarakat Arab, tetapi untuk mengembangkan prinsip-prinsip umum atau hukum-hukum yang mengatur dinamika masyarakat dan proses sejarah (proses perubahan sosial) secara keseluruhan. Ibnu Khaldun kesulitan bersikap objektif dalam menganalisa gejala sosial. Ia memiliki komitmen untuk mencapai tujuan ini. Semangat atau sikap ilmiah dalam menganalisa pada umumnya mendekati bentuk penelitian ilmiah modern dan isinya secara substantif dapat disejajarkan dengan teori sosial modern.

Laurer (2003:49) mengatakan, Ibnu Khaldun mengajukan teori perubahan sosial yang tajam dan salah satu dari sekian pikiran mendalamnya adalah metode historis menawarkan pendekatan terbaik untuk memahami perubahan sosial.

Ibnu Khaldun bukan saja dinobatkan sebagai "Bapak Sosiologi” tetapi juga "Bapak Ilmu Ekonomi", karena teori-teori ekonominya banyak di-copy paste tanpa dicantumkan namanya oleh Adam Smith dan David Ricardo (2009).

Muhammad Hilmi Murad dalam tulisannya yang berjudul $A b u$ Iqtishad, Ibnu Khaldun (www.pewarta-kabarIndonesia, 2009), Ibnu Khaldun adalah penggagas pertama ilmu ekonomi secara empiris. Menurut Murad (2009), Ibnu Khaldun lebih dahulu memaparkan tentang teori kepuasan, teori pasar, dan teori produksi-distribusikonsumsi. Para pemikir dan intelektual Islam meyakini bahwa sebelum memahami pemikiran Ibnu Khaldun, kajian-kajian ekonomi di Barat lebih bersifat normatif, adakalanya dikaji dari perspektif hukum, moral, dan filsafat. Para penggagas ekonomi Barat masih terpesona dan berpijak pada pemikiran ilmuwan-ilmuwan Yunani dan era Scholastik yang bercorak tidak ilmiah.

Berbeda dengan Ibnu Khaldun, ia mengkaji problematika ekonomi suatu masyarakat dan negara secara empiris. Menurut Muhammad Nejatullah Ash-Shiddiqy; "Ibnu Khaldun membahas aneka ragam masalah ekonomi yang luas, termasuk ajaran tentang tata nilai, pembagian kerja, sistem harga, hukum penawaran dan permintaan, konsumsi dan produksi, uang, pembentukan modal, pertumbuhan penduduk, makro ekonomi dari pajak dan pengeluaran publik, daur perdagangan, pertanian industri dan perdagangan, hak milik dan kemakmuran, dan sebagainya. Ia juga membahas berbagai 
tahapan yang dilewati masyarakat dalam perkembangan ekonominya. Kita juga menemukan paham dasar yang menjelma dalam kurva penawaran tenaga kerja yang kemiringannya berjenjang mundur (Murad, 2009).

Murad (2009) juga mengutip pendapat Boulokia dalam Ibnu Khaldun, "A Fourteenth Century Economist" (1971), yang mengatakan: 'Ibnu Khaldun telah menemukan sejumlah besar ide dan pemikiran ekonomi fundamental, beberapa abad sebelum kelahiran resminya (di Eropa). Ia menemukan keutamaan dan kebutuhan suatu pembagian kerja sebelum ditemukan smit dan prinsip tentang nilai kerja sebelum Rikardo ia telah mengolah teori suatu kependudukan sebelum Malthus dan mendesak akan peranan negara didalam perekonomiansebelum Keines bahkan lebih dari itu Ibnu Khaldun telah menggunakan konsepsi-konsepsi ini untuk membangun suatu sistem dinamis yang mudah dipahami dimana mekanisme ekonomi telah mengarahkan kegiatan ekonomi kepada fluktuasi jangka panjang. Penasehat ekonomi Ronald Reagen yang menemukan teori "Laffter Curt". Laffter, jujur mengakui bahwa dirinya mengadopsi gagasan dan pemikiran Ibnu Khaldun. Bagi Laffter, pemikiran Ibnu Khaldun tentang obat resesi ekonomi, yang mengecilkan pajak dan ekspor pemerintah menjadi salah satu landasan kebijakan protek Pemerintah Amerika. Oleh Laffter, gagasan Ibnu Khaldun ini dikembangkan menjadi konsep yang ditempatkan sebagai "ibu" dari semua pasar dalam konteks tingkat pendapatan dan penerimaan. Apabila pasar pemerintahan mengalami penurunan maka akan diakui dengan keleluasan pasar-pasar yang lain (Murad, 2009).

Ibnu Khaldun memiliki pemikiran sejarah yang sangat komperehensif. Beliau tidak hanya menjelaskan metodologi dan teori sejarah secara detail. Ibnu Khaldun mengatakan bahwa sejarah umat manusia sebagai proses yang tak berujung. Selain itu, Ibnu Khaldun seakan-akan menjelaskan masyarakat kota sebagai tujuan proses sejarah dan berulang-ulang dari masyarakat Arab nomaden ke masyarakat kota. Sebagaimana yang digambarkan dalam teori lingkaran sejarah. Karena sejarah dapat saja terulang tetapi kemungkinan lain adalah dalam bentuk penemuan baru sebagai pengembangan sejarah. Pola sejarah masyarakat nomaden kepada masyarakat kota juga terjadi pada masa sekarang, misalnya pada masyarakat transimingran dan masyarakat urban. 
Dengan demikian, pada hakekatnya proses sejarah tidak pernah berakhir. Dengan demikian, Ibnu Khaldun tidak hanya dapat disebut sebagai tokoh ilmu sejarah tetapi juga lebih tepat disebut sebagai sosiolog atau peletak dasar teori sosiologi meski secara eksplisit sebagai sebuah disiplin ilmu dibangun kemudian oleh Auguste Comte (1798-1857) dan Emille Durkheim (1855-1917) serta pada abad yang hampir bersamaan lahir pula tokoh sejarah yang bernama Johan Gottfried von Herder (1744-1803) dengan karyanya yang sangat populer "Ideas for the Philosophy of History of Mankind" (Kuntowijoyo, 2005:55), menjadi salah satu sumber kajian ilmu sejarah dan melengkapi teori-teori sejarah sebelumnya.

\section{PENUTUP}

Pemikiran Ibnu Khaldun tentang sejarah dan sosiologi, pada dasarnya memberi kontribusi bagi dunia intelektual. Teori-teori sejarah dan sosiologinya menjadi pijakan kajian bagi kaum intelektual modern meskipun nama besarnya sempat redup ketika era keemasan intelektual Eropa. Peran para orientalis dan sarjana muslim mengkaji pemikiran para sarjana muslim abad XIV M, membuka mata dunia tentang kualitas pemikiran sarjana-sarjana muslim dan patut dikaji sebagai khasanah keilmuwan khususnya di bidang sejarah dan ilmuilmu sosial. Bahkan para pemikir moderen pun belum ada yang mampu menyamai pemikirannya. Termasuk tokoh-tokoh sosiologi seperti August Comte dari Prancis, Max Weber dari Jerman atau lainnya.

Lingkaran perubahan ikatan sosial atau solidaritas kelompok dalam kehidupan sehari-hari. Perubahannya melalui tiga tahap, yaitu (1) solidaritas sangat kuat yang ditimbulkan oleh kekerasan kondisi kehidupan nomaden di gurun pasir; (2) Munculnya kultur kehidupan menetap dilokasi tertentu dan meningkatnya kemakmuran memperburuk ikatan kelompok dan memperlemah solidaritas; dan (3) ini menyebabkan hancurnya solidaritas sosial, membubarkan kelompok, lalu diikuti oleh kristalisasi kelompok berdasarkan solidaritas sosial baru.

Dalam bagian ini Ibnu Khaldun mengemukakan suatu observasi menarik yang paralel dengan teori sosiologi modern mengenai pembagian kerja dan diferensi sosial.

Kini di dunia Eropa maupun di dunia Islam, nama Ibnu Khaldun menjadi popular seirama dengan perkembangan kajian keilmuwan , khususnya di bidang sejarah dan sosiologi. Dengan demikian, 
pemikiran-pemikiran Ibnu Khaldun dapat dijadikan sebagai rujukan dalam kajian sejarah dan ilmu-ilmu sosial lainnya, serta menjadi kekayaan sejarah bagi masyarakat Islam.

\section{DAFTAR PUSTAKA}

Abdalla, Ulil Absar. Ibnu Khaldun dan Sejumlah Obervasinya ,blogspot" Islam Liberal", JIL, diakses 15 Januari 2008

Gazalba, Sidi. 1983. Islam dan Perubahan Sosiobudaya. Yakarta Pusat: Pustaka Alhusna.

Goodman, George Ritzer-Douglas J. 2004. Teori Sosiologi Moderen. Edisi VI. Jakarta: Prenada Media.

Ibnu Khaldun. 2000. Muqaddimah Ibnu Khaldun. Terjemahan oleh Ahmadie Thoha. Cet. IV. Jakarta: Pustaka Firdaus.

Sztompka, Piotr. 2007. Sosiologi Perubahan Sosial, Cet. III. Jakarta: Prenada Media.

Lauer, Robert H. 2003. Perspektif tentang Perubahan Sosial. Cet. IV. Jakarta: Rineka Cipta.

Muhammad Ibn Tawit at-Tanji. 1951. Autobiography Ibnu Khaldun, yang dikutip dalam bukunya At Ta'rif bi Ibnu Khaldun wa Rihlatuhu Gharban wa Sharqan. Cairo.

Kuntowijoyo. 2005. Pengantar Ilmu Sejarah. Cet. V. Yogyakarta: Bentang.

Murad, Muhammad Hilmi, dalam http:www.pewartakabarindonesia.blogspot.com, diakses 1 September 2009.

Ramadhan, Muhammad Suradi. 2009. Filsafat Sejarah Ibnu Khaldun. Blog. DPD IMM Riau, dikases tanggal 01 September 2009.

Dikutip dari http;www.wikipedia.org/wiki/teori-siklusibnukhaldunwikipedia, 31 Agustus 2009. 